\title{
Estimation of Crop Water Requirement using CROPWAT Model for Maize, A Case Study of Raya Azebo District, Ethiopia
}

\author{
Yemane Mebrahtu Hagos Mehari Yetagesu Nurga Habtamu Tamiru \\ Irrigation and Drainage Research Department, Ethiopian Institute of Agricultural Research, Mekhoni \\ Agricultural Research Center, Ethiopia
}

\begin{abstract}
Water is the major limiting factor for crop production. A lot of water resources have been exploited for irrigation purpose. Irrigation systems essential to enhance crop productivity in order to meet future food demand and ensure food security. Unscientific and injudicious application of groundwater in this district resulted in depletion of the groundwater table. To achieve effective utilization of the groundwater resources, there is a need to estimate the crop water requirement for different crops at different management levels to accomplish effective irrigation management. Crop water requirements of maize crop in Raya Azebo districts was calculated using FAO Cropwat 8.0 a computer simulation model. The simulation study was conducted with the objectives of determining irrigation water requirement maize. The study was carried out to estimate the crop water requirement of maize by using the climatic data, crop evapotranspiration (ETc) and reference crop evapotranspiration (ETo) for each crop were determined using CROPWAT 8.0. The study shows that crop water requirement of maize with a growing period of 125 days to maturity requires $504.0 \mathrm{~mm}$ depth of water on off season and $457.8 \mathrm{~mm}$ on main season respectively. The result shows that in off season the crop water requirement of maize was needed more water than the main season, due to the climatic condition and in the main season the effective rainfall is more available than the off season. This study proved that the CROPWAT model is useful for calculating the crop irrigation needs for the proper management of water resources.
\end{abstract}

Keywords: CROPWAT, Model, Crop water requirement, Maize, Eto

DOI: $10.7176 / \mathrm{JRDM} / 74-03$

Publication date:March $31^{\text {st }} 2021$

\section{INTRODUCTION}

Maize (Zea mays L.) is one of the grain crops of the grass family (F. Rhoads and C. Yonts, 2000) and the world's most important crops besides rice and wheat (J. Zhao and X. Yang, 2017).

Water is the most important and critical input for agriculture and the demand for efficient use of irrigation water for crops is intensifying in view of changing climate. Irrigation water supplies are decreasing day by day and scarcity has been seen in many areas of the world. In India among all the consumers agriculture is the largest end user of water where much effort has to be kept for its efficient use in agriculture (Surendran et al., 2013).

Crop water requirement depend on climatic conditions, crop area and type, soil type, growing seasons and crop production frequencies (FAO, 2009 \& George et al., 2000). Factors affecting the value of the crop water requirement are the value of Crop Coefficient $(\mathrm{Kc})$ and potential evapotranspiration value (ETo). The combination of two separate processes, whereby water is lost on one hand by evaporation from the soil surface and on the other hand by transpiration from a plant, is called evapotranspiration.

Models that simulate the effect of water stress on yield can be valuable tools in irrigation management. However, testing of a model is necessary for its use in a new area while planning water requirement of a crop.

CROPWAT facilitate the estimation of crop evapotranspiration, irrigation schedule and agricultural water requirements with different cropping patterns for irrigation planning and management. Penman-Monteith method (Allen et al. 1998) has been reported to yield consistently more accurate reference evapotranspiration (ETo) estimates across a wide range of climate condition (Jensen et al. 1990; Kashyap and Panda 2001; Irmak et al. 2003).

Different crops have different water use requirements under the same weather condition. Estimation of crop water requirements $(\mathrm{ETc})$ is one of the main components used in irrigation planning, design and operation (Rowshon et al., 2013). (Jensen et al. 1990), provided detailed reviews of the methods commonly used to determine evapotranspiration and estimated crop water requirements.

One way to determine the crop water requirement is by utilizing software Cropwat 8.0 compiled by FAO (Allen et al. 1998).

\section{MATERIALS AND METHODS}

\subsection{Study Location}

Tigray is located in the northern part of Ethiopia with an altitude ranging between 400 to almost 4,000 $\mathrm{m}$ above mean sea level. It is located between $12^{\circ} 15^{\prime} \mathrm{N}$ and $14^{\circ} 57^{\prime} \mathrm{N}$, and $36^{\circ} 27^{\prime} \mathrm{E}$ and $39^{\circ} 59^{\prime} \mathrm{E}$. It covers an area of about $53,000 \mathrm{~km}^{2}(\mathrm{CSA}, 2015)$. The study was conducted in Raya Azebo district, Southern Zone of Tigray, 
Ethiopia. Administratively, Raya Azebo is subdivided into 18 kebeles at an altitude ranging from 930 to $2,300 \mathrm{~m}$ above mean sea level (Tesfay et al., 2014).

The climate is predominantly semi-arid with irregular rainfall accompanied by frequent drought periods. Average annual rainfall ranges from 800 to $1,000 \mathrm{~mm}$ per year reducing to $400 \mathrm{~mm}$ (Edwards et al., 2006).

\subsection{Crop water requirement}

The crop water requirement is the amount of water equal to what is lost from a cropped field by the ET and is expressed by the rate of ET in $\mathrm{mm} /$ day. Estimation of CWR is derived from crop evapotranspiration (ETc) which can be calculated by the following equation.

$\mathrm{ETc}=\mathrm{Kc} \mathrm{X} \mathrm{ETo}$

Where, Kc is the crop coefficient. It is the ratio of the crop ETc to the ETo, and it represents an integration of the effects of four essential qualities that differentiate the crop from reference grass, and it covers albedo (reflectance) of the crop-soil surface, crop height, canopy resistance, and evaporation from the soil. Due to the ET differences during the growth stages, the Kc for the crop will vary over the developing period which can be divided into four distinct stages: initial, crop development, mid-season, and late season.

The reference evapotranspiration ETo is calculated by FAO Penman- Monteith method, using decision support software -CROPWAT 8.0 developed by FAO, based on FAO Irrigation and Drainage Paper 56 (FAO, 2002). The FAO CROPWAT program (FAO, 2009) incorporates procedures for reference crop evapotranspiration and crop water requirements and allow the simulation of crop water use under various climate, crop and soil conditions (www.fao.org).

\subsection{Soil data}

The soil type in this area is a loam and clay. The software needs some general soil data like total available soil moisture, maximum rain infiltration rate, maximum rooting depth, initial soil moisture depletion and initial available soil moisture. This information obtained from FAO manual 56

\section{RESULT AND DISCUSSION}

\subsection{Maize crop}

Estimation of the crop water requirement was carried out by using the historical weather data of the observatory data of the study area (Table 2). The data which was entered in the CROPWAT software included the details type of crop, date of cultivation, harvest and soil type.

Automatically software will compute the ETo, effective rainfall, and total irrigation requirement for the respective crop once the data is fed to the model.

Table 1: Details of the crop required as per the CROPWAT model

\begin{tabular}{|c|c|c|c|c|c|c|c|c|c|c|}
\hline \multirow{2}{*}{$\begin{array}{l}\text { Crop } \\
\text { Name }\end{array}$} & \multirow[t]{2}{*}{ Season } & \multirow{2}{*}{$\begin{array}{l}\text { Planting } \\
\text { date }\end{array}$} & \multirow{2}{*}{$\begin{array}{l}\text { Harvesting } \\
\text { date }\end{array}$} & \multirow{2}{*}{$\begin{array}{l}\text { Critical } \\
\text { depletion }\end{array}$} & \multirow{2}{*}{$\begin{array}{l}\text { Rooting } \\
\text { Depth }\end{array}$} & \multicolumn{5}{|c|}{ Crop growth periods } \\
\hline & & & & & & IS & DS & MS & $\mathbf{L S}$ & Total \\
\hline Maize & Off season & $15-01$ & $20-05$ & 0.55 & $1.0 \mathrm{~m}$ & 20 & 35 & 40 & 30 & 125 \\
\hline Maize & Main Season & $15-06$ & $20-10$ & 0.55 & $1.0 \mathrm{~m}$ & 20 & 35 & 40 & 30 & 125 \\
\hline
\end{tabular}

\subsection{Reference evapotranspiration (ETo)}

The following table (2) gives the Reference Evapotranspiration (ETo) for all the months in a year, in which the highest reference evapotranspiration is found in the month June $(4.7 \mathrm{~mm} /$ day) and the lowest Reference evapotranspiration is found in the month January $(3.3 \mathrm{~mm} /$ day $)$ and November $(3.77 \mathrm{~mm} /$ day $)$ due to differential changes occurs in the weather conditions like temperature, sunshine hours, humidity and wind speed.

In dry season, the resulting low relative humidity combined with high temperatures led to increased evapotranspiration over this period of a year. Inversely the low values of ETo in rainy season may be due to the high frequencies of rainfall combined with high relative humidity and relative low temperatures. As the trend of ETo affecting by climatic factors such as temperatures, solar radiation, and rainfall as well as wind, relative humidity of the air consequently ETo is a climatic parameter. With the variations of these parameters ETo were vary greatly within and between seasons. The results are in accordance with Adeniran et al. (Adeniran et al., 2010), which showed that ETo was lowest during the peak of the rainy season to highest during the peak of the dry season. 
Table 2. Long term monthly average climatic data of the study district

\begin{tabular}{cccccccc}
\hline Month & $\begin{array}{c}\mathbf{T}_{\mathbf{m i n}} \\
{ }^{\circ} \mathbf{C}\end{array}$ & $\begin{array}{c}\mathbf{T}_{\mathbf{m a x}} \\
{ }^{\circ} \mathbf{C}\end{array}$ & $\begin{array}{c}\mathbf{R H} \\
\mathbf{\%}\end{array}$ & $\begin{array}{c}\text { Wind } \\
\mathbf{k m} / \mathbf{h r}\end{array}$ & $\begin{array}{c}\text { Sun } \\
\mathbf{h o u r s}\end{array}$ & $\begin{array}{c}\text { Rad } \\
\mathbf{M J} / \mathbf{m}^{2} / \mathbf{d a y}\end{array}$ & $\begin{array}{c}\mathbf{E T o} \\
\mathbf{m m} / \mathbf{d a y}\end{array}$ \\
\hline January & 11.5 & 27.2 & 73 & 69 & 7.9 & 18.4 & 3.33 \\
February & 12.8 & 27.1 & 70 & 86 & 9.4 & 22.0 & 4.02 \\
March & 13.5 & 29.5 & 68 & 86 & 8.7 & 22.4 & 4.44 \\
April & 13.8 & 29.7 & 67 & 95 & 8.7 & 22.9 & 4.65 \\
May & 15.3 & 32.5 & 58 & 52 & 9.1 & 23.3 & 4.69 \\
June & 15.8 & 35.0 & 60 & 43 & 8.6 & 22.2 & 4.70 \\
July & 15.6 & 31.5 & 90 & 52 & 6.5 & 19.1 & 4.04 \\
August & 15.0 & 29.7 & 95 & 43 & 6.5 & 19.3 & 3.89 \\
September & 14.3 & 30.8 & 74 & 52 & 6.6 & 19.2 & 3.96 \\
October & 13.1 & 29.8 & 69 & 86 & 9.2 & 22.0 & 4.36 \\
November & 12.1 & 28.6 & 67 & 69 & 9.0 & 20.1 & 3.77 \\
December & 11.3 & 27.1 & 69 & 69 & 8.8 & 19.0 & 3.40 \\
\hline
\end{tabular}

\subsection{Crop Water Requirement, Effective rainfall and Irrigation Requirement}

Knowledge of crop irrigation water requirements and irrigation time schedules improves irrigation management in the field. Irrigation water management is about controlling the amount, timing, and rate of irrigation in an efficient and planned manner.

From the below results (Table 2 and 3), It shows that for maize in off season and main season, it requires 504.0 and $457.8 \mathrm{~mm}$ crop water requirement, 36.2 and $122.1 \mathrm{~mm}$ effective rain fall and 468.3 and $335.7 \mathrm{~mm}$ irrigation requirement respectively. It shows that in off season the crop water requirement of maize was needed more water than the main season, due to the climatic condition and in the main season the effective rainfall is more available than the off season.

Table 3. Crop Water Requirement, Effective rainfall and Irrigation Requirement for Maize on Off Season

\begin{tabular}{cccccccc}
\hline Month & Decade & Stages & $\begin{array}{c}\text { Kc } \\
\text { Coef }\end{array}$ & $\begin{array}{c}\text { ETc } \\
(\mathbf{m m} / \mathbf{d a y})\end{array}$ & $\begin{array}{c}\text { ETc } \\
(\mathbf{m m} / \mathbf{d e c})\end{array}$ & $\begin{array}{c}\text { Eff rain } \\
(\mathbf{m m} / \mathbf{d e c})\end{array}$ & $\begin{array}{c}\text { Irr. Req } \\
(\mathbf{m m} / \mathbf{d e c})\end{array}$ \\
\hline Jan & 2 & Init & 0.40 & 1.34 & 8.0 & 0.0 & 8.0 \\
Jan & 3 & Init & 0.40 & 1.43 & 15.7 & 0.0 & 15.7 \\
Feb & 1 & Deve & 0.46 & 1.76 & 17.6 & 0.0 & 17.6 \\
Feb & 2 & Deve & 0.68 & 2.75 & 27.5 & 4.6 & 22.9 \\
Feb & 3 & Deve & 0.89 & 3.70 & 29.6 & 8.4 & 21.2 \\
Mar & 1 & Deve & 1.09 & 4.70 & 47.0 & 0.0 & 47.0 \\
Mar & 2 & Mid & 1.19 & 5.30 & 53.0 & 7.8 & 45.2 \\
Mar & 3 & Mid & 1.19 & 5.39 & 59.2 & 0.0 & 59.2 \\
Apr & 1 & Mid & 1.19 & 5.47 & 54.7 & 10.2 & 44.5 \\
Apr & 2 & End & 1.19 & 5.55 & 55.5 & 0.0 & 55.5 \\
Apr & 3 & End & 1.12 & 5.21 & 52.1 & 5.7 & 47.4 \\
May & 1 & End & 1 & 4.67 & 46.7 & 0.0 & 46.7 \\
May & 2 & End & 0.88 & 4.15 & 37.4 & 0.0 & 37.4 \\
Total & & & & & $\mathbf{5 0 4 . 0}$ & $\mathbf{3 6 . 7}$ & $\mathbf{4 6 8 . 3}$ \\
\hline
\end{tabular}


Table 4. Crop Water Requirement, Effective rainfall and Irrigation Requirement for Maize on Main Season

\begin{tabular}{cccccccc}
\hline Month & Decade & Stages & $\begin{array}{c}\text { Kc } \\
\text { Coef }\end{array}$ & $\begin{array}{c}\text { ETc } \\
(\mathbf{m m} / \mathbf{d a y})\end{array}$ & $\begin{array}{c}\text { ETc } \\
(\mathbf{m m} / \mathbf{d e c})\end{array}$ & $\begin{array}{c}\text { Eff rain } \\
(\mathbf{m m} / \mathbf{d e c})\end{array}$ & $\begin{array}{c}\text { Irr. Req } \\
(\mathbf{m m} / \mathbf{d e c})\end{array}$ \\
\hline Jun & 2 & Init & 0.40 & 1.88 & 11.3 & 0.0 & 16.9 \\
Jun & 3 & Init & 0.40 & 1.79 & 17.9 & 0.0 & 26.9 \\
July & 1 & Deve & 0.45 & 1.90 & 19.0 & 10.9 & 14.7 \\
Jul & 2 & Deve & 0.65 & 2.64 & 26.4 & 16.8 & 11.4 \\
Jul & 3 & Deve & 0.88 & 3.53 & 38.8 & 11.7 & 26 \\
Aug & 1 & Mid & 1.11 & 4.36 & 43.6 & 10.0 & 30.1 \\
Aug & 2 & Mid & 1.17 & 4.55 & 45.5 & 12.8 & 31 \\
Aug & 3 & Mid & 1.17 & 4.58 & 50.3 & 15.1 & 33.6 \\
Sep & 1 & Mid & 1.17 & 4.60 & 46.0 & 14.6 & 29.9 \\
Sep & 2 & Mid & 1.16 & 4.61 & 46.1 & 0.0 & 44.8 \\
Sep & 3 & End & 1.08 & 4.41 & 44.1 & 5.7 & 40.2 \\
Oct & 1 & End & 0.97 & 4.15 & 41.5 & 12.6 & 29.9 \\
Oct & 2 & End & 0.87 & 3.90 & 27.3 & 11.9 & 14.6 \\
Total & & & & & $\mathbf{4 5 7 . 8}$ & $\mathbf{1 2 2 . 1}$ & $\mathbf{3 3 5 . 7}$ \\
\hline
\end{tabular}

\section{CONCLUSION}

The study results enhance our understanding of the water requirements of maize in the study district, which will consequently help improve the management of water resources and the productivity through policies based on these findings. The use of scientific tools like CROPWAT can assess the CWRs with a high degree of accuracy and suggest the crop pattern and crop rotation that farmers can readily accept.

These results can be used for a most efficient water use and to optimize production of the maize in the study district. The results of this study can be used by water resource planners for future planning, thereby helping to save water in meeting the CWRs, and can be used as a guide for farmers to select the amount of irrigation for the crops being studied.

\section{REFERENCE}

Adeniran K A, Amodu M F, Amodu M O, Adeniji F A. 2010. Water requirements of some selected crops in Kampe dam irrigation project. Australia Journal of Agriculture Engineering 1(4): 119-125.

Allen, R. G., Pereira, L. S., Raes, D. and Smith, M. 1998. Crop Evapotranspiration: Guidelines for computing crop water requirements. Irrigation and Drainage Paper 56, FAO of the United Nations, Rome. 300 pp.

Edwards S, Egziabher T, Araya H. 2006. Climate Change and Food Systems Resilience in Sub-Sahara Africa. International Conference on Organic Agriculture and Food Security, held 2-5 May 2007 in FAO, Rome. pp. 231-294.

F. Rhoads and C. Yonts, "Irrigation Scheduling for Corn - Why and How," National Corn Handbook, no. October, Iowa, 2000.

FAO, (Food and Agriculture Organization). 2002. Crop Evapotranspiration Guidelines for Computing crop water requirement. Irrigation and Drainage Paper No. 56

FAO, (Food and Agriculture Organization). 2009. CROPWAT Software, Food and Agriculture Organization, Land and Water Division; Available at: http://www.fao.org/nr/water/infores_data bases_cropwat.html.

George, B., Shende, S., \& Raghuwanshi, N. 2000. Development and testing of an irrigation scheduling model. Agricultural Water Management,46(2), 121-136.

Irmak, S., Allen, R. G. and Whitty, E. B. 2003. Daily grass and alfalfa-reference evapotranspiration estimates and alfalfa to grass evapotranspiration ratios in Florida. J. Irrig. Drain. Engg.129(5):360-370.

J. Zhao and X. Yang, "Distribution of high-yield and high-yield stability zones for maize yield potential in the main growing regions in China," Agric. For. Meteorol, vol. 248, no. October 2017, pp. 511-517.

Jensen, M. E., Burman, R. D. and Allen, R. G. 1990. Evapotranspiration and irrigation water requirements, ASCE manuals and reports on engineering practice, No. 70, ASCE, New York.

Kashyap, P. S. and Panda, R. K. 2001. Evaluation of evapotranspiration estimation methods and development of crop-coefficients for potato crop in sub humid region. Agril. Water Manag.,50:9-25.

R. G. Allen, L. S. Pereira, D. Raes, and M. Smith, "Crop evapotranspiration: Guidelines for computing crop requirements,” Irrig. Drain. Pap. No. 56, FAO, no. 56, p. 300, 1998.

Rowshon M. K., Amin M. S. M., Mojid, M. and Yaji, M. 2013. Estimate evapotranspiration of rice based on pan evaporation as a surrogate to lysimeter measurement. Paddy Water Environment., 13(4): 356-364.

Surendran, U., Sushanth, C. M., Mammen, G., \& Joseph, E. J. 2013. Modelling the crop water requirement using FAOCROPWAT and assessment of water resources for sustainable water resource management: A case 
study in Palakkad district of humid tropical Kerala, India. ICWRCOE: 1211-1219.

Tesfay G, Gebresamuel G, Gebretsadik A, Gebrelibanos A, Gebremeskel Y, Hagos T. 2014. Participatory Rural Appraisal Report: Raya Azebo Woreda, Tigray Region. CASCAPE working paper 2.6.5, website: www.cascape.info. Accessed on 09/02/2016. 